\title{
Depopulation and Migration in the Russian Far East: International, Federal and Local Factors
}

\author{
MATTHEW BENJAMIN LEVIE*
}

\begin{abstract}
Russia faces an acute demographic crisis and labor shortage, and this crisis is most evident in the Russian Far East (RFE). Migration from within Russia and immigration from foreign sources are one potential solution to this crisis. This paper examines the history of migration to the RFE and addresses the questions of where the necessary additional migrants or immigrants might come from and what political, cultural and economic structures might be most effective in mitigating the existing demographic situation.
\end{abstract}

Keywords: Migration, Demographics, Development, Russian Federation, Far Eastern Federal District, Uzbekistan, China, North Korea

* MPA Candidate, Middlebury Institute of International Studies, USA; E-mail: mlevie@miis.edu

DOI: $10.16934 /$ isr.18.2.201712.85 


\section{INTRODUCTION}

Russia today faces one of the most severe demographic crises in the world, due to the combination of a low birth rate, high emigration and the long-lasting effects of two catastrophic events that occurred in the first half of the twentieth century, collectivization and the Second World War. However, if the situation is dire in Russia as a whole, it is catastrophic in the Russian Far East (RFE). The Far East has always required some form of government subsidy to convince Russians to live there, and after the collapse of the Soviet Union, when the subsidies were removed, the population shrank. In the 25 years since 1991, the population of the Far Eastern Federal District has dropped by almost 23\%, and the trend is accelerating as the number of people arriving continues to drop, and the number of people leaving continues to increase (Motrich 2016, 83-84).

Russia as a whole is a very thinly populated country, and the Far Eastern Federal District covers a little over six million square kilometers $(36 \%$ of the territory of the Russian Federation), with a population density of only one person per square kilometer.

The country's leaders today worry that if Russia cannot populate its territory, it may not be able to keep it, and therefore this problem is of international geopolitical importance. In 2000, on a visit to Blagoveshchensk, a city on the Chinese border, Russian president Vladimir Putin said: "If we do not undertake any efforts for the development of the Far East in the near future, then in a few decades the population here will speak primarily Japanese, Chinese and Korean" (Schepp 2016). While Putin himself, as we will see, has moderated this viewpoint, other Russian leaders certainly have not. Lukin and Troyakova adeptly summarize Moscow's dilemma: "completely opening up the area may lead to loss of sovereignty, and closing it off leads to isolation and stagnation" (Lukin and Troyakova 2012, 203).

Migration is perhaps the only possible solution to this problem, and therefore an analysis of migration to and from the RFE is both timely and of vital importance. It is a complex problem, with an entirely unique historical context, involving many countries in an extremely diverse cultural space, where European, Central Asian and East Asian cultures and geopolitical interests interact and often clash. This case study is of particular interest to the migration field, since most migration studies focus on immigration to high-income North American and EU countries, and even within Russia, study of migration and demographics in the RFE is often neglected by academics living in the European part of the country. 


\section{THEORETICAL FRAMEWORK}

Migration is a complex problem which requires a multidimensional, interdisciplinary approach. As Brettell and Hollifield point out, different disciplines are trying to answer different questions when they study migration (3). As a result, we can better understand the causes, effects and influences on migration if we look at it from different angles and use the tools of different disciplines. While the tools and questions of economics and demographics may apply to migration to and from any country, the tools and questions of anthropology and sociology may be specific to the country and even the region under discussion.

The economic analysis of migration rests largely on the concept of cost-benefit analysis (first mentioned in 1889 by Ravenstein, and the many aspects of which are well summarized in Massey 1993). In this view, potential migrants weigh the economic benefits of higher wages in another country against the potential costs of travel and the development of their own human capital. If the benefits are higher, then they migrate. Some theorists integrate cultural considerations into the idea of cost-benefit analysis by considering the time required to learn a new language or integrate into a new culture or to endure xenophobia as a "cost." As Everett Lee succinctly puts it in his 1966 article "A Theory of Migration": While migration may result from a comparison of factors at origin and destination, a simple calculus of +'s and -'s does not decide the act of migration" (51).

There are other theories that allow us to fill in these gaps. The theory of "trust networks" (for example, Tilly 2007) offers an alternative, or at least additional, explanation for the choices of migrants. In this view, migrants follow well-worn paths where their countrymen (or people from their village or region) have gone before. This explains why many migrants from a single village or region will end up in a particular city, and it also explains the dynamic of "enclavization": in other words, the very process that smooths their migration also hinders their integration.

Of course, many Russian analysts have examined Russia's problem of demographics and immigration (e.g. Zayonchkovskaya 2007; Vishnevsky 2009, 2013). However, Russia is a huge country, and the centralizing pull of Moscow applies not only to the populace of the RFE but also to the thinking of many Moscow-based experts and institutions. As a result, this paper relies very heavily on the work of academics living and working in the region, who have studied the problem firsthand for years, such as migration expert Yuri Avdeev, sociologist Ildus Yarulin, historians Viktor Larin and Galina Yermak and demographer Yekaterina Motrich, in addition to nationally known experts such as Zayonchkovskaya and Vishnevky. 
The present case study is valuable for a number of reasons. Most migration studies are focused on immigration to high-income countries, but migration to middle-income countries such as Russia and South Africa is common. In fact, of the top 10 migration corridors in 2013, four were among states that were formerly part of the Soviet Union, and in fact only two involve a high-income country (Mexico-US and China-US) (Migration Factbook 20). Therefore research is needed to verify that commonly accepted theories of migration also apply to these cases.

Second, Russia sometimes deviates from theory in other areas. For instance, the mystery of Russia's high death rate confounds public health researchers (Eberstadt 62). In the sphere of migration, Russia is no less a country of contradictions. For example, the main source of migrants to the RFE are Uzbeks, who are simultaneously "culturally distant" (Muslim and Turkic, where Russians are Orthodox Christian and Slavic) and "culturally close" (having a shared recent history as part of the USSR and to some degree Russian-speaking). Another contradiction: Slavic individuals frequently express a preference for Uzbek and Tajik migrants on the basis of this cultural proximity over Chinese migrants, who are viewed as a potential political threat and demonstrate no cultural proximity at all. This distinction informs public policy in Russia and Chinese immigration to the RFE is severely restricted. However, public opinion surveys generally reveal no such distinction.

Third, Russian public policy towards immigration changes frequently and there is tension in this case between the policies imposed by the center and the needs of the periphery. Russian law is notable both for its extreme severity and for being honored more in the breach than in the observance (as a popular Russian saying has it: "the severity of Russian law is compensated for by the fact that it is not necessary to observe it"). As such, Russia provides an interesting potential case study in terms of the effectiveness of public policy, or rather, the effects of public policy, intended or unintended.

\section{METHODOLOGY}

A complex problem such as migration also requires the use of mixed methods. Quantitative data sources used include economic data on the overall health of the Russian economy, data on entry of foreign citizens into the Russian Federation and applications for work permits, and public opinion surveys conducted both nationwide and within the region.

However, there are major weaknesses in the available quantitative data. The Russian federal statistics service ("Rosstat") provides a wide variety of data, but the statistical validity of the data is often suspect and it can take years for Rosstat to post particular data. As a result, a rigid adherence to statistical 
approaches is liable to provide a partial or even incorrect picture of the problem. In addition, the unit of analysis for economics is very broad.

Since the situation with regard to migration can change quickly, and migration decisions are made by individuals, qualitative methods were used to supplement the quantitative data and provide the clearest, most up-to-date possible picture of the situation on the ground. It is hoped that by examining the situation from the top quantitatively and the bottom qualitatively, a more complete picture can be achieved. In an attempt to capture as many voices as possible in the analysis, more than two dozen interviews were conducted in and around the cities of Vladivostok and Khabarovsk with academics (some of whom had access to preliminary statistical data not yet available to the public), leaders of relevant nonprofits, leaders of local migrant communities, and migrants themselves. All interviews were conducted in Russian to avoid any possibility of miscommunication. Government officials would not agree to interviews with an American researcher due to the tense political situation between the United States and Russia, but ample information on the local political situation was available in the local press, which was also thoroughly examined and cited.

\section{STATEMENT OF THE PROBLEM}

There are various reasons that it is hard to keep people in the RFE: the climate is harsh, transportation costs are high, which makes consumer goods expensive, and the Far East feels poorly integrated with the rest of Russia. From Vladivostok you can reach Seoul or Tokyo in two hours by plane, and Shanghai in three-but Moscow is an eight-and-a-half-hour flight away. In addition, the Far East is a relatively new part of Russia- Vladivostok and Khabarovsk, the region's largest cities, were founded in the mid-19th century, and a large part of the population arrived only during the Soviet regime, attracted by generous financial incentives. As a result, most people have very weak roots in the region, especially compared to European Russia, where families may have been living for centuries. When children who grew up in the RFE go to Moscow or St. Petersburg for university, many of them do not return. 


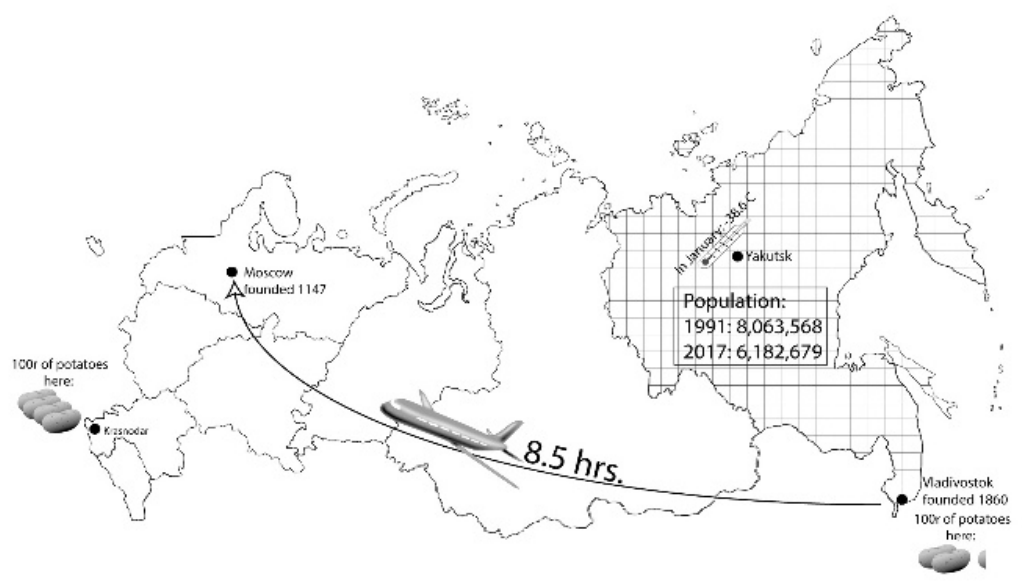

FIGURE 1. REASONS FOR LOW POPULATION IN THE RUSSIAN FAR EAST.

Not only is the region losing population, but it is losing exactly the people it needs most--young people of working and reproductive age. In 2016, natural population decline was briefly arrested, and some advocates declared victory. But in the first months of 2017 population decline has begun again. This is due to the outmigration of women of childbearing age, and government proposals to return the population to 1991 levels by 2050 are simply not realistic (Personal interview, Yekaterina Motrich, March 30, 2017). This has led to a critical labor shortage in the Far East: in the Primorskiy Region, which includes Vladivostok, for example, there were 3.5 vacancies for every unemployed worker in 2013 (Loboda 2014, 42).

\section{V. "MIGRANTS" AND "IMMIGRANTS"}

We need to acknowledge some difficulty with definitions. The words "migrant" and "immigrant" are ill-defined within the Russian context. Politicians tend to refer to "migrants," because it preserves the fiction that they will leave, and demographers tend to refer to "immigrants," because they understand that a long-term solution to Russia's demographic problems requires these migrants to stay, take Russian citizenship, and continue to contribute to the growth of the population in future generations (Avdeev 2017). As a result, in this paper we will use the term "migrants" as a default, and "immigrants" to describe people who have already made the decision to stay in Russia permanently, with the understanding that these may simply represent the same people at different points in their migratory journey. 
More than $70 \%$ of Tajik and Kyrgyz migrants say they want to "leave temporarily and return fairly soon" (Mansoor and Quillin 2006, 18). The vast majority of migrants are men, who work in Russia and send remittances home. These remittances are a huge part of the economies of the countries of origin: $42 \%$ of the GDP of Tajikistan and $29 \%$ of the GDP of Kyrgyzstan are due to remittances (Uzbekistan does not provide this information) (Ratha, Plaza, and Dervisevic 2016, xii). However, for Central Asian migrants, returning home is unrealistic and rarely happens, partly because there is nothing to return home to, and partly because they begin to feel at home where they have settled. More often, sometimes after a decade or more of working abroad, one of two things happens: if the migrants are single when they arrive, they marry a local woman (often an ethnic Russian) and settle down, and if they are married, they send for their families and take Russian citizenship. (A. Bakhovadinov, personal interview, March 28, 2017) In fact, one Tajik immigrant interviewed explained that he had a wife in Tajikistan, a wife in Kazan, where he lived when he first came to Russia, and a wife in Vladivostok: "I'm doing my part to fix Russia's population problem!" he proudly exclaimed (Anonymous, personal interview, March 28, 2017).

This is much rarer among migrants from China or North Korea, because they tend to take seasonal work and work in "brigades" where only the leader actually speaks Russian. As a result they do not integrate into the local culture, intermarry, or stay long-term and receive citizenship, according to Sergey Pushkarev, Chairman of the "Consultative Center on Migration Issues and Interethnic Relations" in Vladivostok (Personal interview, March 22, 2017).

The difference in migration patterns is not easily explained by economic theory. After all, if purely economic circumstances push an Uzbek and a Chinese person to emigrate to the RFE, it will require a different kind of analysis to explain why the Uzbek works year-round as a bus driver, stays permanently and may even marry a Russian woman and take Russian citizenship, while the Chinese works seasonally in agriculture, does not interact with the local population and does not settle permanently in Russia. The theory of "trust networks" partially explains this: migrants settle in locations where people from their country, and in many cases their village, have migrated before. Because the RFE and Tajikistan (for example, but this reasoning also applies to Uzbekistan) were both part of the closed system of the Soviet Union, there were Tajiks in the RFE before the collapse of the Soviet Union and before Tajikistan was a separate country. These Tajiks provided a "soft landing" for their countrymen who wished to immigrate to post-Soviet Russia. No such trust network existed for potential Chinese migrants.

However, seasonal labor needs are not easily filled by Tajiks because Tajikistan is too distant, and it is too expensive to return every year, therefore it is 
more convenient for these positions to be filled by Chinese (or in some cases, North Koreans). However, this process results in the formation of much flimsier "trust networks."

We must also acknowledge that it is not a coincidence that this distribution of labor, where Central Asians form the permanent migratory underclass and Chinese do seasonal agricultural work, suits the preferences of the Slavic population of the RFE. In other words, we may explain the result by economic or sociological forces, but we cannot ignore the fact that these results are greatly influenced by public policy and the desires of the existing population of the RFE. As we see in the next section, Russian legal frameworks are deliberately oriented towards this result.

\section{LEGAL FRAMEWORKS OF MIGRATION}

The difference in roles that migrants fill in Russian society is a function of the legal framework that allows them to work there. There are three ways a foreigner can currently work in Russia:

- For citizens of the Eurasian Economic Community (EAEC)-in addition to Russia, members are Belarus, Armenia, Kyrgyzstan, and Kazakhstan - no work permit is needed. These citizens only need to show a signed work contract and they are entitled to work in the Russian Federation indefinitely. These are, not coincidentally, the countries where the population is most likely to speak Russian fluently, even a quartercentury after the collapse of the Soviet Union. According to Samat Toktobolotov, vice-consul at the Kyrgyz embassy in Moscow, this makes Kyrgyz workers much sought after in Russia (Denisenko 2016).

- Citizens of most other CIS (former Soviet) countries have visa-free access to Russia. This category includes Uzbeks, the most numerous non-Slavic migrants in Russia and the RFE. If they wish to work in the country, they have 30 days after crossing the border to find work and pass exams in the Russian language, culture and law, obtain medical insurance and demonstrate that they are healthy, all of which qualifies them for a "patent na rabotu" ("work patent"). These requirements (exams, insurance and medical exam) were initiated on January 1, 2015 as a result of new legislation governing migration in the Russian Federation. On the one hand, this ensures that migrants from CIS countries speak enough Russian to get by and understand their rights under Russian law, and it theoretically makes the procedure for getting a work patent more predictable and thus discourages illegal migration. 
In practice, it is very difficult to do all of these things in 30 days, and it is also expensive: migrants must pay 14,500 rubles for the work permit and 4,000 every month to renew it, and they must undergo medical tests and buy health insurance. So forged documents (which may be cheaper and do not require passing the tests) and illegal migration continue.

- Citizens of all other countries (for example, China and North Korea) must apply for a "razreshenie na rabotu" (work permit) in their country of origin. As a result, migration from these countries is very difficult and fairly rare, even in the RFE- $80 \%$ of migrants in the RFE are Uzbeks (S. Pushkarev, personal interview, March 22, 2017). Due to the Far East's proximity to these countries, illegal immigration is not difficult or uncommon. It is, of course, impossible to say exactly how many illegal Chinese workers there are in the RFE, but simply visiting the region's major cities it is obvious that there are few of them by comparison with Uzbeks and Tajiks.

\section{ATTITUDES TOWARDS MIGRANTS}

There have always been a wide variety of nationalities living within Russia's borders, and the Soviet Union was a multinational state. In the 1950s, the "Great Vladivostok" project brought laborers from all over the Soviet Union to the city, and the APEC summit in 2012 did the same, and locals have been very accepting (Avdeev and Pushkarev 2011, 19). The physical confrontations between migrants and "nativist" Russians that have occurred in other regions are absent in the RFE. In fact, Bahodir Nurakov, director of the "Adolat" center for Uzbek migrants in Vladivostok, says that Uzbeks who leave the region for Moscow or St. Petersburg often report that they felt they were better treated in the Far East (Personal interview, March 23, 2017).

However, this perceived tolerance may be due simply to the fact that the RFE has a lower proportion of migrants than the regions where these more violent conflicts occur, or it may reflect the political immaturity of the anti-immigrant forces in the region, or both. In fact, past experience shows that large-scale migration, when it happens too quickly, does have negative consequences, even in the RFE. In the early 1990s, a visa-free regime with China allowed Chinese guest workers and day traders to flood into the region. Reaction both in Vladivostok and in Moscow was very negative, and visas were soon reinstated (Larin 2005, 50). The massive influx of mostly Uzbeks required to complete the infrastructure projects for the 2012 APEC summit, despite Avdeev and Pushkarev's statements to the contrary, also generated some negativity (VL.ru 2011). 
Opinion surveys paint a more complex picture. In a 2013 public opinion survey in Kamchatka, $25.9 \%$ of Russians said they relate "kindly" and $45.8 \%$ "neutrally" to members of other nationalities, with only $17.4 \%$ saying they "experience dislike" (Ogiy 2014, 22). However, when asked how they felt about particular ethnic groups coming to work in their city, ethnic Russians were much less welcoming: 41\% felt "negatively" about immigrants from Belarus, Ukraine and Moldova, 61\% felt negatively about migrants from China, Vietnam and other non-CIS countries, 63\% felt negatively about migrants from Azerbaijan and Armenia, and 68\% felt negatively about migrants from Central Asia (Ogiy 2014, 29). Similar survey results have been reported from the Khabarovsky region in 2013 (Yarulin, Slonsky, and Suschev 2014, 64).

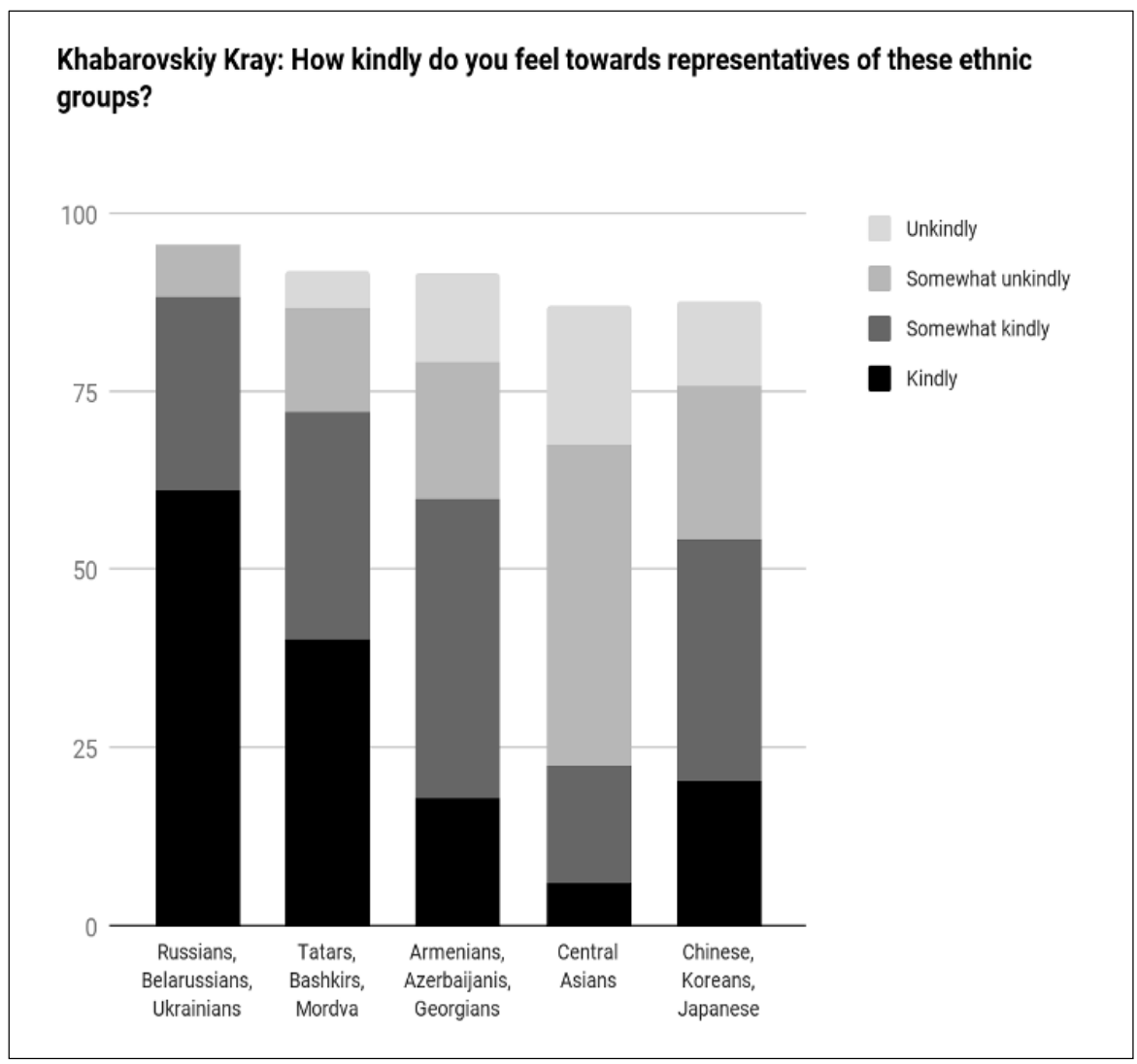

Source: Yarulin, Slonsky, and Suschev 2014, 64.

FIGURE 2. FEELINGS OF ETHNIC RUSSIANS IN KHABAROVSKY KRAY. 
However, the population of the Primorskiy Kray, the most diverse subunit of the Far Eastern Federal District, is still 92\% Slavic (Avdeev 2017) and some federal efforts have focused on attracting migration from European Russia and the migration of Slavic peoples currently living outside Russia.

\section{POTENTIAL SOURCES OF SLAVIC MIGRATION}

In general, these efforts are well-meaning but doomed to failure, because it is hard to justify this migration on the basis of either cost-benefit analysis or trust networks. From 2007-2010, the central government operated a program called "Sootechestvenniki" ("fellow countrymen"), which aimed to attract ethnic Russians from abroad. Despite spending four billion rubles a year (about \$131 million, using the conversion rate on January 1,2011 ) on the program, it attracted only 28,086 people to Russia, and of those only 1,017 to the RFE (Vaschuk 2014, 158 and 213).

The crisis in Ukraine has actually had several positive one-time effects on Russia's overall demographic problems. There is no evidence, of course, that these effects have motivated any of the actors in the crisis, but it should be pointed out that the humanitarian situation in eastern Ukraine has provided a significant increase in the Slavic population in Russia. From April 1, 2014 to December 31, 2015, a total of 1.1 million people fled from eastern Ukraine into Russia (Federal Migration Service 2016, 15) as "refugees." These refugees were given enormous financial support (over 13 billion rubles) (Federal Migration Service 2016, 16) as well as a legal framework to legally work and receive Russian citizenship. In addition, it should be pointed out that Russia's population gained almost 1.5 million Russians and about 350,000 Ukrainians overnight when the Russian Federation annexed Crimea. This is based on the Russian post-annexation census, so the exact ethnic breakdown may be disputed, but ironically, despite all the hatred that has been aimed at Ukrainians by the Russian mass media, it is clear from the previously mentioned opinion surveys that Russians still prefer Ukrainian migrants to non-Slavic ones.

While this massive influx of Slavic migrants may have contributed to an improvement in the demographic situation of western Russia, it has had a negligible effect on the Russian Far East. Despite the fact that many residents of the RFE are of Ukrainian descent, and despite explicit government attempts to encourage Ukrainian refugees to settle there, only about 4,000 of them actually made the trip (S. Pushkarev, personal interview, March 22, 2017).

Recently, the Ministry for the Development of the Far East has announced the "free Far Eastern hectare," a heavily-promoted program where any Russian citizen can receive free land in the region if they agree to work the land themselves. 
Based on research which shows that " $6 \%$ of Russians declared unequivocally that they are prepared to take a plot in the Far East," the Ministry estimates that 8 million people might take advantage of this offer (Ministry of Far Eastern Development 2017b). However, from its inception on June 1, 2016 through April 2017, the Ministry reported only 84,000 applications. Of these, $17 \%$ were rejected (Ministry of Far Eastern Development 2017a) and the Ministry does not say how many people have actually occupied their hectares.

Most local experts, however, think it is unlikely to provide any significant immigration, since potential migrants do not know what plot they will receive until they get there, and most of the plots are far from infrastructure (many are not accessible by road) and agriculture on many of them is simply not profitable (for example, they may be located in a swamp). In addition, even if such plots could be made profitable, this requires the investment of capital, which can be far more profitably invested elsewhere in Russia or abroad (G. Yermak, personal interview, March 27, 2017; and Y. Motrich, personal interview, March 30, 2017).

One of the principles identified by Lee is that migrants responding to factors at the destination tend to be positively selected (56). In other words, potential likely migrants in this case tend to be relatively educated and well off, and in order to attract more people to the destination, you need to provide factors that will appeal to people who are under no necessity to migrate. The experience of the Far Eastern hectare program seems to support this hypothesis: growing vegetables in a swamp in the RFE is unlikely to appeal to Muscovite elites who are looking for better opportunities.

We can conclude, then, that there is little prospect of another massive influx of culturally adapted, Slavic, Christian, Russian-speaking immigrants in the near future. If so few of the refugees from Ukraine ended up in the Russian Far East, perhaps distance was a factor. In that case, can we expect that China might provide a demographic boost to the region? Zhanna Zayonchkovskaya, in her seminal 2007 article "Immigration: there is no alternative," believed that immigration from China was both necessary and unavoidable, and that someday Chinese would be the second most numerous ethnic group in the Russian Federation, behind Russians.

\section{MIGRATION FROM CHINA}

In the early 1990s, a visa-free regime between China and Russia contributed to an influx of Chinese migrants, mostly entering on tourist visas. However, this influx also occasioned a considerable backlash (Larin 2005, 50). This was felt on the local level, but more keenly on the federal level, as fears that the Chinese would colonize the Far East and subject it to creeping annexation rose. (Tikhookeanskaya pravda 2001). As a result, in 2000, visa-free travel was restricted 
to groups traveling under the aegis of a licensed tourism company and limited to 30 days (Larin 2005, 50).

Concerns about Chinese flooding the Russian Far East after the collapse of the USSR appear to have been overblown, although occasional paranoia resurfaces-as late as 2000, as the visa-free regime was ending, Aleksandr Shaikin, head of border control at the Federal Migration Service, claimed that over 1.5 million Chinese had illegally entered the Far Eastern Federal District over the previous 18 months (Stratfor.com 2000). That number seems highly unlikely ${ }^{-}$and as of 2017, there is no visual evidence in Vladivostok and Khabarovsk, the region's largest cities, of such a flood of illegal Chinese immigration. If we recall that the entire population of the RFE is about six million, it seems highly improbable that such a significant number of Chinese could be present in the RFE without this being extremely obvious even to the casual observer, which it is not.

Moreover, there is plenty of work in China, and there appears to be little desire on the part of Chinese citizens to settle permanently on the Russian side of the border (Larin 2005, 48). If Chinese from the province of Heilongjiang just across the border from the RFE have a desire to seek their fortune elsewhere, they are more likely to seek it in the south of their own country (Y. Avdeev, personal interview, March 24, 2017).

In 2015, according to the Federal Service for Government Statistics ("Rosstat"), 12,416 people arrived in the Far Eastern Federal District from non-CIS countries, and 11,971 left. Since the vast majority of "non-CIS" migrants are Chinese (North Koreans are a very distant second), we can use this number as a proxy for the number of legal Chinese migrants and provisionally conclude that there are very few. We need to keep in mind that there may be many more illegal migrants than legal ones, but all the same, this seems to indicate that Chinese (and other East Asians) are interested mostly in seasonal work, such as in the agriculture, construction or timber industries ${ }^{-}$or, as mentioned earlier in the section on the legal framework, that Russian immigration policy has been constructed to make that the only option available to them. As a result, some experts, like Yuri Avdeev of the Pacific Institute of Geography, believe "the window has closed" on Chinese immigration (Personal interview, March 24, 2017). 


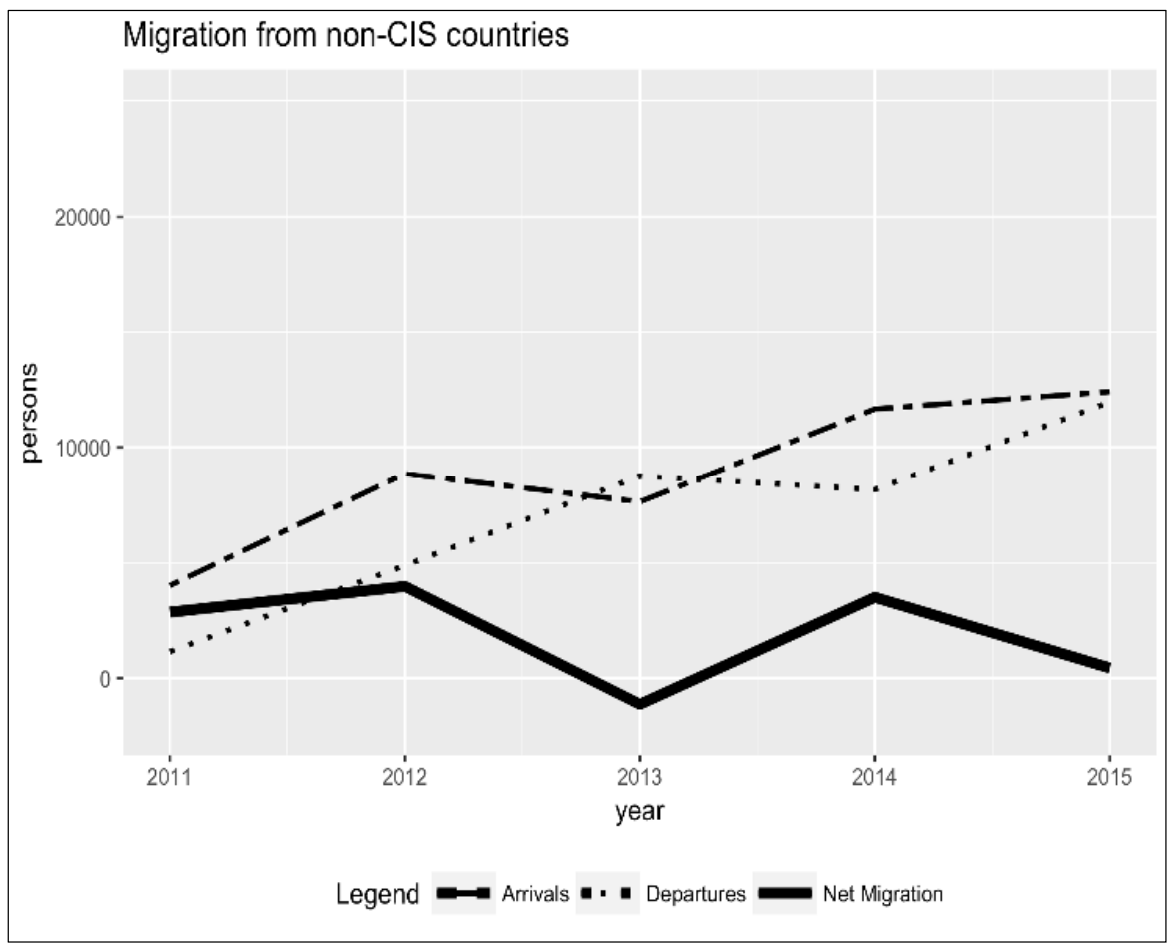

Source: Rosstat.

FIGURE 3. MIGRATION FROM NON-CIS COUNTRIES TO THE RUSSIAN FAR EAST.

\section{MIGRATION FROM CENTRAL ASIA}

A more important source of immigration is Central Asia, which still shares a common history (and, in some parts, a common language) with Russia, and Central Asia, in particular, has a young population and a serious unemployment problem.

The number of Central Asian children in Russian schools is a testament to this. According to some sources, in 8-10 years, a third of children in Russian schools will be Russian language learners (RG.ru. 2012).

The creation of the Eurasian Economic Union (EAEU) formed a single market for goods and labor (but no political structures) between Belarus, Russia, and Kazakhstan. Armenia joined the next day, and Kyrgyzstan entered the union on August 6. The countries other than Russia in the EAEU are among the most Russified of the former Soviet states, so they are ideal for providing migrant labor that meets the necessary cultural criteria. But the largest sources of migrant labor in Central Asia, Uzbekistan and Tajikistan, were left outside of the EAEU (in Uzbekistan's case by choice, while Tajikistan is still negotiating). The result was 
that the potential influx was more than offset by the tightening of labor permits, which affected Uzbeks and Tajiks, and the worsening Russian economy, and migrants actually began to leave the region.

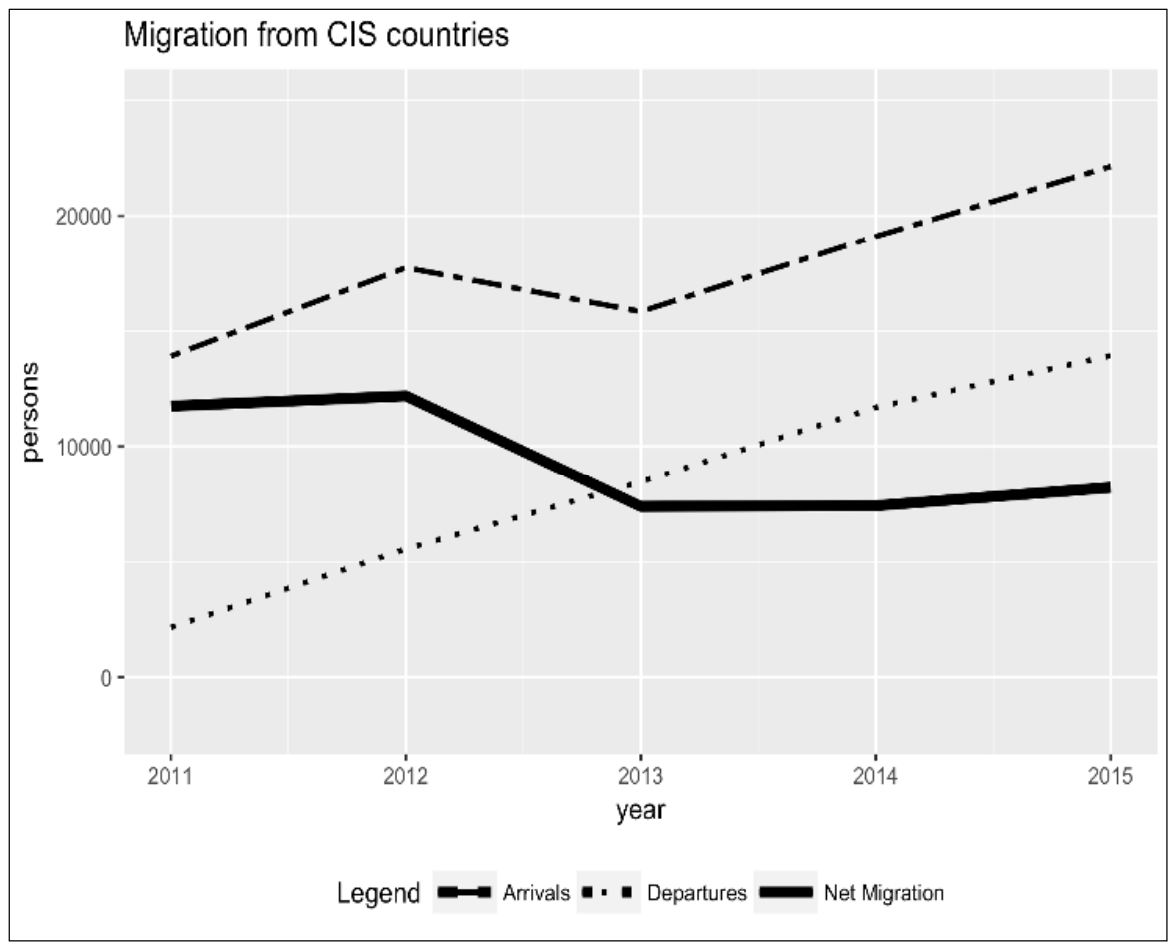

Source: Rosstat.

\section{FIGURE 4. MIGRATION FROM CIS COUNTRIES TO THE RUSSIAN FAR EASTERN FEDERAL DISTRICT.}

In comparison with Figure 2, it is evident that the number of migrants from CIS countries is far greater than from non-CIS countries. Anecdotally, "CIS countries" may be taken as a proxy for "Uzbekistan," just as "non-CIS countries" was earlier taken as a proxy for "China." And while there is almost certainly also a large contingent of illegal immigrants from Central Asia, it is reasonable to assume that the trends for legal and illegal migration are the same, since the push and pull factors operating on both of them are the same.

If that is true, then migration is flat when it needs to be climbing to reverse the population decline in the Far East. For the last three years of this period, we saw a gain of something like 7,500 migrants from Central Asia. But they were not enough to offset the overall trend, seen here: 


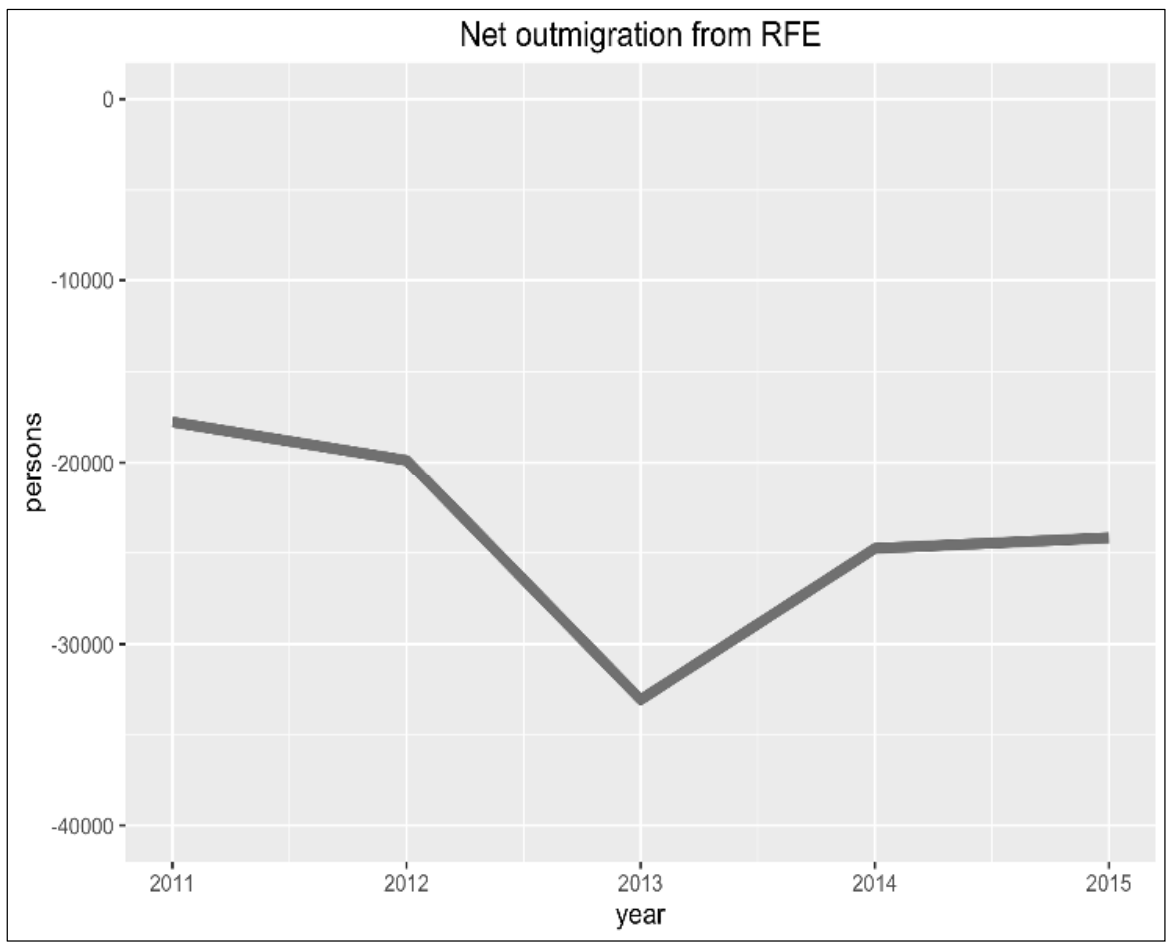

Source: Rosstat.

FIGURE 5. TOTAL OUTMIGRATION FROM THE RFE, 2011-15.

It is evident that in 2011-2012, when net migration from Central Asia was higher, overall population loss in the RFE was also lower. The higher migration in 2011-12 is best explained by the massive infrastructure projects undertaken in Vladivostok in preparation for the 2012 APEC summit, for which large amounts of migrant labor were needed. But once the infrastructure projects were complete, many of those migrants left, either for their home countries or for the European part of Russia. This continues a trend in RFE population dynamics that was mentioned at the beginning of the paper: most residents are attracted by some kind of temporary benefit, and when the benefit is removed, a good proportion of those migrants leave. In the case of the migrants who worked on the APEC summit projects, this trend was exacerbated by the slowing Russian economy.

Bahodir Nurakov, director of the "Adolat" center for Uzbek migrants, confirms anecdotally that the economy has taken a heavy toll on migrants (Personal interview, March 23, 2017). In addition, the falling ruble makes migrant work less attractive to those sending money home to Uzbekistan (Stanchik 2015). However, there is no significant correlation between the dollar exchange rate of the ruble on June 1 of each year and the number of migrants leaving the Far Eastern Federal 
District.

However, if we correlate the number of migrants leaving the region with the annual growth in Russian GDP, we find a very significant correlation (r-squared for CIS migrants: 0.8618, for non-CIS migrants: 0.8607, both correlations, $\mathrm{p}<.05$ ). While this cannot prove causation, it stands to reason that fewer opportunities in the Russian economy will result in fewer opportunities for those with the fewest qualifications and the most precarious legal status, in other words, migrant workers. This would seem to support the cost-benefit analysis of migration, but only partially. There is no correlation between the state of the economy and people arriving in the region, which underscores the fact that people in donor countries have very incomplete information about conditions at the destination.

In other words, we can say that economic conditions at the source are a more important influence on the migratory stream, while economic conditions at the destination are a more important influence on the counterstream. Once again, we find that Lee understood this decades ago: "There are, however, important differences between the factors associated with the area of origin and those associated with the area of destination. Persons living in an area have an immediate and often long-term acquaintance with the area and are usually able to make considered and unhurried judgments regarding them. This is not necessarily true of the factors associated with the area of destination. Knowledge of the area of destination is seldom exact, and indeed some of the advantages and disadvantages of an area can only be perceived by living there" (50). The migratory policies of most countries are predictably oriented towards increasing or decreasing the influx of migrants, but our case would seem to underscore that this is likely to have a delayed or negligible effect.

We also cannot rule out the effect of the tightening of migration rules as of January 1, 2015, mentioned above. By only giving potential migrants 30 days to fulfill a very long and difficult list of requirements, legal migration has been put on a much sounder footing, but the number of legal migrants has been reduced. It is impossible to know if this decrease was offset by an increase in illegal migration, but it is likely that some potential migrants unable to pass the Russian language, history and law exams simply chose to purchase forged documents. Again, theory would seem to indicate that tightening policy at the destination will have little to no effect on the migratory stream, especially in a country like Russia (or any post-Soviet country), where finding a way around the law is extremely common.

In one way, long-term trends in the global and regional labor markets are not favorable to immigration to Russia from Central Asia. Other countries, such as Turkey, Kazakhstan, the United Arab Emirates, and South Korea are also thirsty for labor, and these destinations may be more desirable for Uzbeks looking 
for a better life. South Korea and Dubai offer higher wages than Russia, and Turkey and Kazakhstan share these migrants' Muslim religion. Kazakhstan is particularly desirable because it is physically close and the Kazakh language is very easy to learn for Uzbeks (Eurasianet.org 2016). In other words, some countries are able to offer more "benefits," meaning higher wages, and some are able to offer lower "costs," in terms of more cultural and linguistic familiarity.

\section{CONCLUSION}

Despite Central Asian immigration, the population of the Far Eastern Federal District continues to fall. Some, such as Zhanna Zayonchkovskaya, believe that there is simply not enough available labor in Central Asia, and massive migration from China is the only option: "The flow of Chinese is not only a threat, but also a necessity for Russia," she writes. "That is, a threat that we cannot avoid." It has been suggested by others that Russia should begin importing labor from India and Bangladesh (Lukin and Troyakova 2012, 202). Some, like Yuri Avdeev, believe that the Far East should simply accept that the loss of population is unavoidable, and plan for it: "objectively the situation is such that there is no possibility of influencing the steady demographic and migratory trends, and it follows from this that it is necessary to orient oneself towards those types of economic activity that do not require a large quantity of people, and that will maintain their sustainability even if the population falls further" (Avdeev 2016, 180). Avdeev proposes that the region focus on three areas: space exploration, marine industries, and culture (ibid.)

But even if potential migrants can be found, questions remain whether the Russian populace, currently in a phase of increased nationalism, can absorb the number of immigrants necessary to prevent demographic collapse. Some policymakers may understand the necessity of immigration, but like in the United States, individual citizens are susceptible to panic resulting from isolated violent events, such as the cases of the Uzbek nanny who beheaded her charge and the ethnic Uzbek from Kyrgyzstan who committed the April 3, 2017 subway bombing in Saint Petersburg. Ildus Yarulin believes that sectors of society which are inclined against immigrants have also become more proficient at manipulating the media, and social media, in response to these isolated criminal incidents (Yarulin 2014a, 12).

What is likely to occur in the future? The Slavic populations that form the preferred migrant population simply are not interested in living in the RFE: the incentives at the destination are insufficient and conditions at the source are not bad enough. Yuri Avdeev's suggestion that Russia simply resign itself to a slow population drain from the area and focus on industries that can survive this loss of population is the most likely result. After all, the population of the region has 
been decreasing for twenty-five years despite significant government attention and investment, and realistically, this is unlikely to change. However, from a geopolitical standpoint, this solution may not satisfy Moscow, which will continue to look across the border at the tens of millions in Heilongjiang, Jilin and Liaoning provinces and worry about "creeping annexation."

If Moscow is really determined to increase the population of the region, non-Slavic immigrants are the only option. And not just temporary "guest workers": the workers must be encouraged to bring their families, learn the language, settle down, and contribute to the future population growth of the region. This will require the deepening of "trust networks" and greater efforts to integrate new migrants. As we have seen, changing conditions at the destination is unlikely to be very effective, at least not in the short term: it is unknown how long Russian changes in government policy take to filter down to remote villages in Uzbekistan's Fergana Valley. However, there are government-initiated measures that can impact a potential migrant's cost-benefit calculation by changing conditions at the source.

One such suggestion comes from Bahodir Nurakov of the "Adolat" center quoted in the preceding analysis and an immigrant himself (Personal interview, March 23, 2017). He suggests that if Russia is serious about attracting migrant labor, it should follow the example of South Korea, the prime destination for Uzbek migrant labor. While South Korea hosts relatively few Uzbek workers compared with Russia, and the migration process there is certainly not without its problems, there are many lessons that Russia might learn from the Uzbek-South Korean relationship. South Korea, like Russia, is also experiencing a labor shortage resulting from a low birth rate. In contrast to Russia, labor permits for South Korea are issued in Uzbekistan by the Labor Ministry on the basis of demand from South Korean employers. This way, the Uzbek government can identify the right workers before they enter Korea, the workers have time to learn some Korean language and culture, and they know what their salary will be and where they will be working ${ }^{-}$and living-before they leave.

By contrast, in Russia the migrant worker does not know what job, if any, awaits him in Russia or what salary he can expect, and must rely on his fellow countrymen to house and feed him until he gets a job, which they inevitably do, either through their mosques or their civic associations (A. Bakhovadinov, personal interview, March 27, 2017). This system helps migrants get on their feet, but it contributes to "enclavization" of foreign communities and hinders integration into the host society.

The South Korean system would be very attractive to potential Uzbek interests. Looked at from an economic perspective, the South Korean system provides more information, allowing potential migrants to better calculate the "costs and benefits" of migration. While Russia cannot offer the salaries that 
South Korea can offer, it can offer many times more jobs than South Korea, Turkey and Kazakhstan combined-as attractive as those countries may be to potential Uzbek migrants. In addition, for migrants willing to settle permanently in their host country, Russia is more attractive. South Korean work permits have strict time limits designed to prevent migrant workers from settling permanently in the country (Mundy 2013), while Russian citizenship is relatively easy to obtain. This too is a potential "benefit" Russia can offer.

This solution might be attractive to Russians, as well, if Uzbek immigrants were farther up the curve in terms of learning the language and customs when they first arrived. The shorter cultural-linguistic distance between the native and migrant populations would also lower the cost of social integration to migrants, and perhaps reduce enclavization. It might also reduce criminality, since new migrants who cannot find a job are logically more likely to seek illegal ways of supporting themselves. In other words, this policy can reduce costs to both migrants and Slavic populations. The RFE should see modest increases in migration which provide tangible economic benefits and noticeable demographic results, and this should limit "backlash" and allow the policy to become self-sustaining.

In fact, employers in the Primorye region agree that this would be a good idea, and have discussed opening a recruitment center in Uzbekistan themselves, but lack the resources to undertake the project on their own (S. Pushkarev, personal interview, March 22, 2017; D. Dega, personal interview, March 25, 2017). This would be an especially good idea, because leaving migration policy entirely to the central authorities in Moscow is simply likely to draw more migrants to the areas where they are already going, following their existing "trust networks"-that is, the European part of Russia. While it would cost money, it could certainly be done for less than the four billion rubles annually spent on the ill-fated "Sootechestvenniki" ("fellow countrymen") program, and would no doubt provide more tangible results.

Lastly, it is important for Russia to decide if it is willing to accept the consequences of immigration. Hostile attitudes towards migrants exist even in those areas of the RFE where very few migrants have settled (Ogiy 2014, 29; Yarulin, Slonsky, and Suschev 2014, 64; Larin 2005, 58). In a February 2017 survey, $38 \%$ of Russians polled nationwide said they felt "negatively" about migrants from Central Asia, up from 31\% ten years before (Yuri Levada Center 2017). This is two years after the legal reform that was supposed to reduce illegal immigration and ensure that migrants who did receive permission to work in Russia had a good command of Russian language, history, and law. However, this polling data has not been disaggregated to the RFE, and it is possible that the region's self-image of a more tolerant society has some beneficial effect. Historically, there are precedents that demonstrate that Russian xenophobia can be overcome: a significant number of highly assimilated Koreans live in the RFE. 
They have been living there for generations and are considered "nashi"-"ours"by Russians.

So Russia is at a crossroads. Its demographic destiny demands more tolerance, but politicians continue to stoke anti-migrant sentiment. Which route it takes now may well determine its fate at midcentury.

\section{REFERENCES}

Avdeev, Yuri A. 2016. "The potential of the labor market for the conquest of the Far East" (Потенциал рынка труда для освоения Дальнего В остока). In The demographic development of the Russian Far East (Дем ографическое развитие российского Дальнего Востока) edited by Sergey Ryazantsev and Marina Khramova, 179-188. Moscow: Ekon-Inform.

Avdeev, Yuri A. 2017. "Danger: Immigration" (Осторожно: иммиграция). Manuscript received from author, March 23, 2017.

Avdeev, Yuri A., and Sergey Pushkarev. 2011. "Do migrants threaten Russia's national security?” (Угрожают ли мигранты безопасности Росс ии?) Migratsiya XXI veka 7: 17-19.

Avdeev, Y. (2017, March 22). Personal interview.

Bakhovadinov, A. (2017, March 27). Personal interview.

Brettell, Caroline B., and James F. Hollifield. 2015. Migration Theory: Talking Across Disciplines. New York: Routledge.

Dega, D. (2017, March 25). Personal interview.

Denisenko, Evgeniy. 2016. "Toktobolotov: Entry into the EAEC has seriously changed the status of migrant workers" (Токтоболотов: Вступление в ЕАЭС серьезно изменило статус трудовых мигрантов). In vb.kg, last modified April 4, 2016, accessed March 3, 2017. http://www.vb.kg/ doc/337451_toktobolotov:_vstyplenie_v_eaes_serezno_izmenilo_statys_tr ydovyh_migrantov.html

Eberstadt, Nicholas. 2010. Russia's Peacetime Demographic Crisis. Seattle: National Bureau of Asian Research.

Eurasianet.org. 2016. "Eastern promises: why Central Asian migrant workers are turning their backs on Russia." The Guardian, last modified May 19, 2016, accessed August 31, 2017. https://www.theguardian.com/world/2016/may/19/ eastern-promises-migrant-workers-turning-backs-russia

Federal Migration Service of the Russian Federation. 2016. "A summary report on the migration situation, results and fundamental directions of activity of the Federal Migration Service during 2015" (Итоговый доклад о миграционной ситуации, результатах и основных направл ениях деятельности Федеральной миграционной службы з 
a 2015 ГОД). Last modified February 19, 2016, accessed February 23, 2017. https://Гувм.мВД.pф/upload/site1/document_file/Itogovyy_doklad na_19.02.16.pdf

Larin, Viktor. 2005. "Chinese in the Russian Far East: Regional Views," in Crossing National Borders: Human Migration Issues in Northeast Asia, edited by Tsuneo Akaha and Anna Vassilieva, 47-67. Tokyo: United Nations University Press.

Lee, Everett S. 1966. “A Theory of Migration.” Demography 3(1): 47-57.

Loboda, O. V. 2014. "An institutional analysis of the prospects for integration of labor migrants into the social space of the Primorsky Кray" (Институци ональный анализ перспектив интеграции трудовых мигра нтов в социальное пространство Приморского края). In Interethnic and interconfessional relations in the Far Eastern Federal District (Межэтнические и межконфессиональные отношени я в Дальневосточном федеральном округе) edited by Ildus Yarulin, 41-55. Khabarovsk: Pacific State University Press.

Lukin, Artyom, and Tamara Troyakova. 2012. "The Russian Far East and the Asia-Pacific: State-Managed Integration." In from APEC 2011 to APEC 2012: American and Russian Perspectives on Asia-Pacific Security and Cooperation edited by Rouben Azizian and Artyom Lukin, 189-203. Vladivostok and Honolulu: Far Eastern Federal University and AsiaPacific Center for Security Studies.

Mansoor, Ali and Bryce Quillin, eds. 2006. Migration and Remittances: Eastern Europe and the Former Soviet Union. Washington: The World Bank.

Massey, Douglas S., et al. 1993. "Theories of International Migration: A Review and Appraisal." Population and Development Review 19(3): 431-466

Ministry of Far Eastern Development of the Russian Federation. 2017a. "The number of rejections for a 'Far Eastern hectare' has fallen almost in half." (Количество отказов на 'дальневосточный гектарь' сокра тилось почти вдвое), last modified April 21, 2017, accessed May 8, 2017. https://minvr.ru/press-center/news/4711/?sphrase_id $=5800$

Ministry of Far Eastern Development of the Russian Federation. 2017b. "The Far Eastern hectare" (Дальневосточный гектарь). Undated, accessed May 8, 2017. https://minvr.ru/activity/razvitie-msp-i-konkurentsii/dalnevostochnyygektar/

Motrich, Yekaterina L. 2016. "Migratory components of the demographic development of the Far Eastern Federal District" (Миграционные компоненты демо графического развития Далневосточного федерального окру га). In The demographic development of the Russian Far East. (Демографи ческое развитие российского Дальнего Востока) edited by Sergey Ryazantsev and Marina Khramova, 81-91. Moscow: Ekon-Inform. 
Motrich, Y. (2017, March 30). Personal interview.

Mundy, Simon. 2013. "S Korea struggles to take in foreign workers," in The Financial Times (London), last modified September 17, 2013, accessed August 31, 2017. https://www.ft.com/content/afcdefd4-1c1c-11e3-b678-00144feab7de

Nurakov, B. (2017, March 23). Personal interview.

Ogiy, O. G. 2014. "Problems of ethnic and religious tolerance in Kamchatka: an outline of the risks" (Проблемы этнической и религиозной тол ерантности на Камчатке: контур рисков). In Interethnic and interconfessional relations in the Far Eastern Federal District (Межэтн ические и межконфессиональные отношения в Дальневос точном федеральном округе) edited by Ildus Yarulin, 15-40. Khabarovsk: Pacific State University Press.

Pushkarev, S. (2017, March 22). Personal interview.

Putin, Vladimir. "The Russian economy cannot do without migrants" (Российс кой экономике не обойтись без мигрантов). Speech, Moscow, Russian Federation, January 12, 2011. Accessed on RIA Novosti. https://ria.ru/ economy/20110112/320823075.html

Ratha, Dilip, Sonia Plaza, and Ervin Dervisevic. 2016. Migration and Remittances Factbook 2016, third edition. Washington: The World Bank.

Ravenstein, E.G. 1889. "The Laws of Migration." Journal of the Royal Statistical Society LII: 288.

RG.ru. 2012. "Educational (mi)grant." (Мигрант на обучение), in rg.ru, last modified October 12, 2012, accessed February 20, 2017. https://rg.ru/ 2012/10/02/migranty.html

Schepp, Matthias. 2016. “The Chinese sword” (Китайский меч), in profile.ru, last modified May 9, 2011, accessed October 31, 2016, http://web.archive.org/ web/20131001110441/, http://www.profile.ru/items_32127

Stanchik, Sergey. 2015. "Migrant workers are leaving the Primorye region in droves" (Трудовые мигранты массово покидают Приморье), in vestiprim.ru, last modified January 15, 2015, accessed February 20, 2017. http://vestiprim.ru/news/ptrnews/16507-trudovye-migranty-massovopokidayut-primore.html

Stratfor.com. 2000. "Russian Far East Turning Chinese?" In stratfor.com, last modified July 7, 2000, accessed April 19, 2017. https://www.stratfor.com/ analysis/russian-far-east-turning-chinese

Tikhookeanskaya zvezda. 2001. "Chinese in the Russian Far East" (Китайцы н a российском Дальнем востоке).] In Tikhookeanskaya zvezda [Pacific Star], last modified May 4, 2001, accessed May 8, 2017. https://www.toz.khv.ru/newspaper/arkhiv/2001_05_04_kitaytsy_na_rossiy skom_dalnem_vostoke_norma_ili_ugroza/

Tilly, Charles. 2007. "Trust Networks in Transnational Migration.” Sociological 
Forum 22(1): 3-24.

Todaro, Michael P. 1976. Internal Migration in Developing Countries. Geneva: International Labor Office.

Vaschuk, A.S. et al. 2014. Historical problems of sociopolitical security of the Russian Far East (second half of the XX century-beginning of the XXI century. Book 2. Migratory challenges and strategies of securing sociopolitical security of Far Eastern territories. (Исторические проб лемы социально-политической безопасности российского Дальнего Востока (вторая половина XX-начало XXI в.) Кни га 2. Миграционные вызовы и стратегии обеспечения соци ально-политической безопасности дальневосточных терр иторий). Vladivostok: Institute of history, archaeology and ethnology of the peoples of the Far East, Far Eastern branch of the Russian Academy of Sciences.

Vishnevsky, Anatoly. 2013. "The new role of migration in the demographic development of Russia" (Новая роль миграции в демографичес ком развитии России), in russiancouncil.ru, last modified April 23, 2013, accessed April 12, 2017. http://russiancouncil.ru/inner/\%3Fid_4\% $3 \mathrm{D} 1752$

Vishnevsky, Anatoly. 2009. The Challenges of Russia's Demographic Crisis. Paris/ Brussels: IFRI Russia/NIS Center.

Vishnevsky, Anatoly. 2013. "The new role of migration in the demographic development of Russia" (Новая роль миграции в демографичес ком развитии России), in russiancouncil.ru, last modified, accessed November 2, 2017. http://www.russiancouncil.ru/analytics-and-comments/analytics/ novaya-rol-migratsii-v-demograficheskom-razvitii-rossii/

VL.ru. 2011. "Migration specialists: Vladivostok is flooded with unqualified workers from the "near abroad."” (Специалисты по миграции: Вла дивосток наводнен неквалифицированной рабочей силой из ближнего зарубежья). In VL.ru. Last modified December 1, 2011, accessed February 20, 2017. http://www.newsvl.ru/first_person/ 2011/12/01/96178/

Yarulin, Ildus F. 2014a. "Basic approaches to the study of ethnicity and the methodology of the study of interethnic relations" (Основные подход ы к изучению этничности и методология изучения межэтн ических отношений). In Interethnic and interconfessional relations in the Far Eastern Federal District (Межэтнические и межконфес сиональные отношения в Дальневосточном федеральном округе) edited by Ildus Yarulin, 3-14. Khabarovsk: Pacific State University Press.

Yuri Levada Analytical Center. 2017. "Not enough defense for migrants" (Мигр 
антам не хватает защиты), last modified April 28, 2017, accessed May 11, 2017. http://www.levada.ru/2017/04/28/migrantam-ne-hvataetzashhity/

Yarulin, I. F. 2014b. "A 'new' conquest of the Far East" ("Новое” освоение Д альнего востока). In Interethnic and interconfessional relations in the Far Eastern Federal District (Межэтнические и межконфессион альные отношения в Дальневосточном федеральном окру ге) edited by Ildus Yarulin, 79-90. Khabarovsk: Pacific State University Press.

Yarulin, K. I., E. S. Slonsky and M. P. Suschev. 2014. "The dynamics of interethnic and interconfessional relations in Khabarovsky Kray" (Динамика меж этнических и межконфессиональных отношений в Хабаро вском крае). In Interethnic and interconfessional relations in the Far Eastern Federal District (Межэтнические и межконфессиональ ные отношения в Дальневосточном федеральном округе) edited by Ildus Yarulin, 56-78. Khabarovsk: Pacific State University Press.

Yermak, G. (2017, March 27). Personal interview.

Zayonchkovskaya, Zhanna A. 2007. "Immigration: there's no alternative” (Имми грация: альтернативы нет), in Are Immigrants Necessary to Russian Society? (Нужны ли иммигранты российскому общест By?) edited by V. I. Mukomel and A. Pain, 7-30. Moscow: "Liberal Mission" Fund. 